\title{
Experimental design for chemical mixtures: A case study on a molten salt system conductivity
}

\author{
Oğuz Akpolat ${ }^{1 *}$, Atila Göktaş ${ }^{2}$ \\ 1* Muğla Sıtkı Koçman University, Science Faculty, Chemistry Department, Muğla, Türkiye (ORCID: 0000-0002-6623-4323), oakpolat@mu.edu.tr \\ ${ }^{2}$ Muğla Sttkı Koçman University, Science Faculty, Statistics Department, Muğla, Türkiye (ORCID: 0000-0001-7929-2912), gatilla@mu.edu.tr
}

(First received 11 August 2021 and in final form 16 December 2021)

(DOI: $10.31590 /$ ejosat.981410)

ATIF/REFERENCE: Akpolat, O. \& Göktaş, A. (2021). Experimental design for chemical mixtures: A case study on a molten salt system conductivity. European Journal of Science and Technology, (31), 55-60.

\begin{abstract}
Experimental studies in many fields such as chemistry, biochemistry, food and environmental sciences require very well designed experimental strategies to achieve the best results at minimum cost. At this point experimental design means application of statistical methods to the selection of experimental process factors and to the modelling of system responses to them. Models in which experimental results are expressed depending on experimental factors are also called response surface functions. Mixture designs as a special type of response surface function are also a very effective method for determining the proportions of components in mixtures and are also of great importance in chemical industries like paint, food, glass, ceramic and polymer. Physicochemical properties such as thermal-physical properties, fusion enthalpy, heat capacity, density, thermal stability and conductivity for pure materials or their mixture can be determined experimentally by thermal analysis methods depends on their ingredients. In this study to design molten salt mixtures for thermal energy storage, computational thermodynamics approach has been applied on an experimental design sample. For this purpose conductivities of a molten salt system with three components were measured experimentally depending on the relative ratio of each component, and the effect of these ratios on the conductivity of the mixture was investigated. Here, mixture design model chosen for optimization of process parameters is Simplex Lattice, and Design Expert 700 software were used for statistical analysis. After the model selection for experimental design and transformation of the all factors, the correlation coefficients of the response surface function with linear, quadratic and cubic terms based on all factors for experimental measurements and pseudo and real factors were determined separately. Comparing with the others the best fit of the response surface function sufficient for optimization of process parameters to the experimental measurements was found out for that of with quadratic terms.
\end{abstract}

Keywords: Molten salt, Thermal-physical properties, Experimental design, Response surface

\section{Kimyasal karışımlar için deneysel tasarım uygulamaları: Ergimiş tuz sisteminin iletkenliği üzerine bir örnek çalışma}

$\ddot{O} \mathbf{z}$

Kimya, biyokimya, gıda ve çevre bilimleri gibi pek çok alanda deneysel çalışmaların minimum maliyette gerçekleştirilmesi ve en iyi sonuçlara ulaşılabilmesi çok iyi tasarlanmış deney stratejilerine ihtiyaç duyar. Bu noktada yapılacak deneysel tasarım, istatistiksel yöntemlerin deneysel süreç faktörlerine uygulanması demektir. Deneysel sonuçların deneysel faktörlere bağlı olarak ifade edildiği modeller de cevap yüzey fonksiyonu olarak adlandırılır. Özel bir cevap yüzey fonksiyonu türü olan karışım tasarımları da karışımlardaki bileşenlerin oranlarını belirlemede çok etkili bir yöntemdir ve boya, gıda, cam, seramik ve polimer endüstrilerinde büyük önem sahiptir. Burada yapılan örnek çalışmada termal-fiziksel özellikler, füzyon entalpisi, 1sı kapasitesi, yoğunluk ve termal stabilite gibi özellikler termal analiz yöntemleri ile deneysel olarak belirlenebilmektedir. Yine buradaki örnekte termal enerji depolaması için yenilikçi erimiş tuz karışımları tasarlamak bu hesaplamalı termodinamik yaklaşımı uygulanmıştır. Bu amaçla, her bir bileşenin nispi oranına bağlı olarak iletkenliği deneysel olarak ölçülen sahip üç bileşenden oluşan bir erimiş tuz sistemi seçilmiş ve bu oranların karışımın iletkenliği üzerinde etkisi araştırılmıştır. Burada proses parametrelerinin optimizasyonu için seçilen karışım tasarım modeli Simplex Lattice olup, istatistiksel analiz yapmak için Design Expert 700 yazılımı kullanılmıştır. Deney tasrımı için model seçimi ve faktörlerin dönüşümü sonrasında, tüm faktörlere bağlı cevap yüzey fonksiyonunun doğrusal, ikinci dereceden ve kübik terimlerle korelasyon katsayıları ve sözde ve gerçek faktörler için ayrı ayrı hesaplanmıştır. Optimizasyon için ikinci dereceden terimlere sahip cevap yüzey fonksiyonun uyumu yeterli kabul edilmiştir.

Anahtar Kelimeler: Ergimiş tuz, Termo-fiziksel özellikler, Deneysel tasarım, Cevap yüzey fonksiyonu..

*Corresponding Author: oakpolat@mu.edu.tr 


\section{Introduction}

Today, studies in many fields such as chemistry, biochemistry, food and environmental sciences are carried out experimentally in laboratories for quality control, raw material and product analysis required for semi-finished and finished products. In order to perform these experimental studies at minimum cost and in optimum conditions, well-designed experimental strategies are needed. This is only possible with experimental design, and experimental design is based on the application of statistical methods to experimental process factors. These steps essentially constitute the experimental procedure followed, and this is to determine the number of experiments and experimental factor limitations for each study and to select a model and numerically analyze the optimization function to describe the correlation between the experimental results and factors. The response surface methodology reduces number of experimental trials required for multi-factor experiments too. Therefore, the function for response surface can be expressed in some linear or nonlinear models. Mixture design, a special type of response surface function, is a very effective method of determining the proportions of variables or components of a mixture, and it is frequently encountered in industries like paint, food, glass, ceramic, frits and polymers etc.. In chemistry, a mixture refers to any combination of the substances that make up it, while statisticians define it as a factor set whose sum is constant. For example, ingredients in a solvent system in HPLC or a product such as food or paint are considered a mixture, and each ingredient can be specified as a part, and the total varies from $1 \%$ to $100 \%$. The response may be the separation constant for a food stuff test, while the conductivity may be the response of a molten salt mixture. A standard design approach is not suitable for mixture design types and can not be applied because the proportions are up to one. In this case, a mixture with $q$ components is expressed by the following equation:

$$
\sum_{i=1}^{q} x_{i}=1 \quad 0 \leq x i \leq 1 \quad i=1,2, \ldots, q
$$

where $x_{i}$ represents the ratio of the $i^{\text {th }}$ component in the mixture. $\mathrm{Q}$ components form a regular (q-1) dimensional Simplex. Certain points need to be taken into account in selecting the appropriate mix design; these are the number of factors, the interactions to be studied, the complexity of each design, the statistical validity and effectiveness of each design, the ease of implementation and cost and time constraints associated with each design. Simplex-Lattice is one of the commonly used mix design types, and SimplexCentroid design for $\mathrm{A}[\mathrm{k}, \mathrm{m}]$ is defined as follows:

$N=\frac{(k+m-1) !}{(k-1) ! * m !}[2]$

where $\mathrm{k}$ is the number of components, $\mathrm{m}$ is the highest order interaction and $\mathrm{N}$ is the total number of experiments. For a mixture design example identified by A [3,3] and shown in Figure e-ISSN: 2148-2683
1 , only the test number is calculated by the formula $\mathrm{N}-\mathrm{m}$. The ratio of I to show any component in the design matrix created for a three-factor mixture is given for Sheff model with the following equation:

$$
\left.C_{i-\text { real }}=C_{i-\text { coded }} *\left(U_{i-\text { coded }}-L_{i-\text { coded }}\right)+L_{i-\text { coded }}\right)
$$

Here $\mathrm{U}$ and $\mathrm{L}$ are the upper and lower boundaries of the components, and the first step is to propose a mathematical model of this surface and to simulate it. Some linear or nonlinear models can be used as a function of the response surface. Here, a linear model without parabolic effects of three factors is given as an example. When the models are examined, only the linear (L) (xi), the quadratic $(\mathrm{Q})\left(\mathrm{xi}{ }^{*} \mathrm{xi}\right)$ and the cubic one are defined by $(\mathrm{C})$ (xi*xi*xi).

$y=b_{0} x_{0}+y_{L}+y_{Q}+y_{C}$

where,

$y_{L}=b_{1} x_{1}+b_{2} x_{2}+b_{3} x_{3}$

$y_{Q}=b_{12} x_{1} x_{2}+b_{13} x_{1} x_{3}+b_{23} x_{2} x_{3}$

$y_{C}=b_{123} x_{1} x_{2} x_{3}$

Calculation of the coefficients in a mathematical model bases on another minimization process the sum of the differences between the responses from the model and their experimental values, and called the least squares method. The written optimization function for the response surface is as follows (Akpolat, 2016; Brereton, 2003; Buruk Sahin, et al., 2016; Coskun and Akpolat, 2012; DesignExpert v.7., 2005).

$J=\sqrt{\sum_{i=1}^{n} d_{i}^{2}}=\sqrt{\sum_{i=1}\left(y_{i-\operatorname{exp~erim~}}-y_{i-\text { calcul }}\right) 2} \rightarrow$ Min

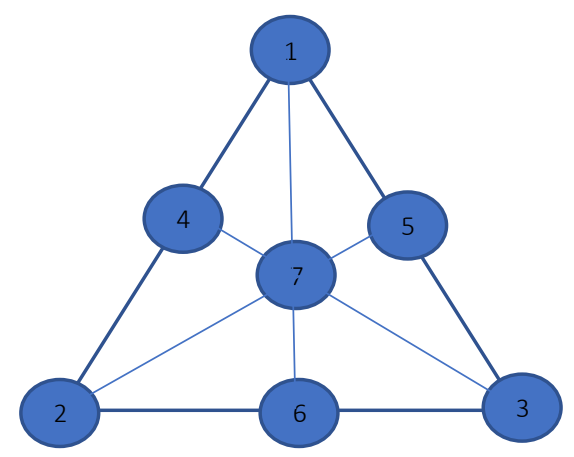

Figure 1. Three factor Simplex lattice design example

One of the application areas of mixture designs is molten salts and their different industrial uses. Molten salts form an important class of fluids for high temperature applications. Their simplest example is to liquefy sodium chloride to red by heating it to a temperature higher than $801^{\circ} \mathrm{C}$. This liquid has the same volume 
as water, stable as it has similar heat capacity and fluid like water. The major difference is the markedly high temperatures that can be obtained in molten salt form, and when salt solidifies, it loses volume unlike water and therefore freezing of molten salt does not burst the pipe like water. Salts are simply ionic and stable compounds. Sodium is one of the most electropositive substances and always one of the most electronegative for electron exchange is chlorine. These two oppositely charged substances easily combine to form stable sodium chloride via a strong ionic bond.

Solid sodium chloride does not conduct electricity; It is an insulator, if it is soluble in water it causes the mutual attraction bonds of both sodium $(\mathrm{Na})$ and chlorine $(\mathrm{Cl})$ to water molecules to break in it, dissolve and form charged atoms or molecules ions. These electrically charged ions can conduct electricity if there is a voltage potential. The "Downs Cell" takes advantage of this electrical conduction to produce almost all the metallic sodium the industry needs. Electricity is passed through molten sodium chloride (some calcium chloride salt is added to lower the melting point of sodium chloride). Chlorine gas is released at one terminal (anode) and liquid sodium at the other (cathode). Molten salt technology is an all-encompassing statement that includes many different technologies as electrochemistry or heat transfer in reactors. All these technologies are related to the general properties of molten salts: they act as a solvent and have good heat transfer properties like a fluid (water) heat capacity function, attain very high temperatures, conduct electricity, and have some catalytic properties.

Molten salts are also used in many industries as heat transfer media for high temperatures: most of them are non-ferrous metal aluminum, titanium production units, solar power towers, fuel cells, molten salt oxidation - coal gasification units, chemical weapons and nuclear reactors. Such technologies operate in the temperature ranges provided by molten salts due to their main properties: stability at high temperatures, low vapor pressure, liquid state over a wide temperature range, ability to dissolve many inorganic and organic compounds, generally low viscosity and high heat capacity per unit volume are the most important properties. For the correct design and sizing of heat exchangers and other auxiliary equipment, it is very important to have accurate data for the thermos - physical properties of the fluids used. Therefore, the data for these new mixtures need in the future.

The thermal-physical properties of eutectic salt mixtures such as fusion enthalpy, heat capacity, density, thermal stability and conductivity can be determined experimentally by thermal analysis methods. In this study, it focused on an experimental design application for conductivities of a molten salt system and statistical evaluation of the results for mixture design applications. For this purpose, a molten salt system having three components with measured conductivities experimentally was chosen to investigate the conductivity relationship the mixing ratio of each component by response surface methodology. Here, the mixture design chosen for the optimization of process factors was e-ISSN: 2148-2683
Simplex-Lattice and DesignExpert 700 software was used for statistical analysis (Akpolat, 2016; http://moltensalt.org/whatIsMoltenSalt.html, 2019; Li, et al., 2018; Nunes, et al., 2016; Özdemir, 2012).

\section{Experimental and Methods}

\subsection{Use of a Constrained Mixture Design to Investigate the Conductivity of a Molten Salt System}

The basic principles of the designs used for modeling chemical mixtures base on the composite design, illustrated by a three-factor example at the corner of the triangle shown in Figure 1. The first step of the design is to code the factors and it is always important to choose reasonable physical values for each of the factors. The central point of each factor is assumed to be 0.5 between 0 and 1 , and the design is symmetrical around it. In the case of the mixture Simplex-Lattice design model, the three factors are the mixing ratios of the salts, namely (1) $\mathrm{NdCl}_{3}$, (2) $\mathrm{LiCl}$ and (3) $\mathrm{KCl}$, and the response of the design is the conductivity of the molten salt measured depending on the mixing ratio of each component in $\%\left(\Omega^{-1} \mathrm{~cm}^{-1}\right)$. Here, the total number of experiments $(\mathrm{N}=7)$ was calculated by Equation 2 for $\mathrm{A}[\mathrm{k}=3$ and $\mathrm{m}=3]$. The limits of the experimental study and the results of the experiments are given in Table 1 and Table 2. In the experiments, the value of 1 corresponds to the upper limit and 0 to the lower limit, supported by pseudo-components. (Akpolat, 2016).

Table 1. The boundaries of the experimental study

\begin{tabular}{|l|l|l|l|}
\hline & & Lower limit & Upper limit \\
\hline$x_{1}$ & $\mathrm{NdCl}_{3}$ & 0.2 & 0.9 \\
\hline$x_{2}$ & $\mathrm{LiCl}$ & 0.1 & 0.8 \\
\hline$x_{3}$ & $\mathrm{KCl}$ & 0.0 & 0.7 \\
\hline
\end{tabular}

Table 2. The experimental results

\begin{tabular}{|l|l|l|l|}
\hline $\boldsymbol{z}_{1}$ & $\boldsymbol{z 2}_{\mathbf{2}}$ & $\boldsymbol{z 3}$ & $\begin{array}{l}\text { Conductivity } \\
\left(\mathbf{\Omega}^{-\mathbf{1}} \mathbf{c m}^{-\mathbf{1}} \mathbf{)}\right.\end{array}$ \\
\hline 1 & 0 & 0 & 3.98 \\
\hline 0 & 1 & 0 & 2.63 \\
\hline 0 & 0 & 1 & 2.21 \\
\hline 0.5 & 0.5 & 0 & 5.54 \\
\hline 0.5 & 0 & 0.5 & 4.00 \\
\hline 0 & 0.5 & 0.5 & 2.33 \\
\hline 0.3333 & 0.3333 & 0.3333 & 3.23 \\
\hline
\end{tabular}

Design Expert 700 software menu steps was followed for the optimization of mixing parameters of molten salts using a oneway Simplex-Lattice design (DesignExpert v.7., 2005). In the optimization procedure, the constrained mixing space was shown schematically by a triangle in the original mixing 
space. In the real mixing space, a design matrix consisting of seven columns was produced, the actual composition of each component is $\mathrm{Z} 1(\mathrm{U} 1-\mathrm{L} 1)+\mathrm{L} 1$, where $\mathrm{U}$ and $\mathrm{L}$ are the upper and lower boundaries of the component. Using this equation, after transforming all three columns of the above matrix it was set up a design matrix containing three single-factor terms and two and three interaction terms using Sheff'e model relating the conductivities to the ratios of the three salts, and statistically estimated the conductivities for different ratio of salts. The effects of the linear (L), quadratic (Q), and cubic (C) terms of the response surface function model on the optimization were compared.

\subsection{Mixture Design Steps by Soft-Ware}

Interface of the Design Expert program and Experimental Design data page for Simplex Lattice are given in Figure 2 and in Figure 3, mixture design steps carried out on the software named Design Expert 700 program are as follows:

1. Model selection by the soft-ware and introduction of the process factor limits and the process factors with responses measured experimentally given in Table 1 and Table 2 to the program.

2. Getting transformed process factors with responses in real and coded forms.

3. Determining of correlations for response surfaces with or without linear, quadratic and cubic terms of the model with factors given by Equation 4 statistically.

4. Simulation of the response surface and factors for optimization.

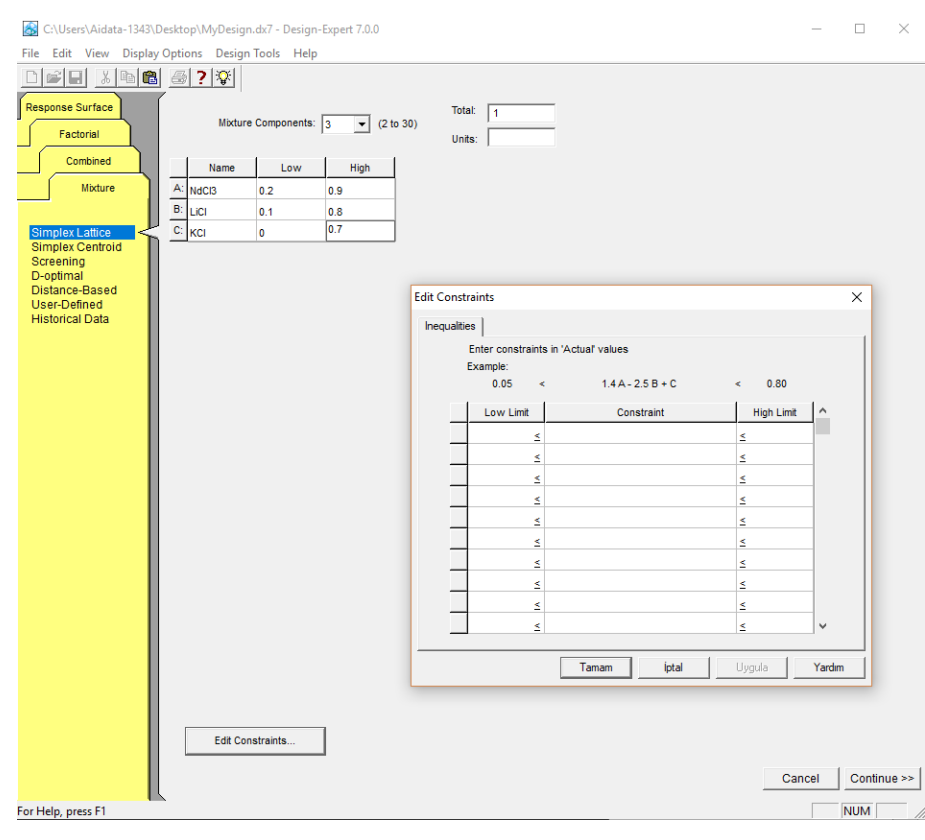

Figure 2. Interface of the Design Expert program for Simplex Lattice

\section{Results and Discussion}

\subsection{Limitations and Transformed Factors}

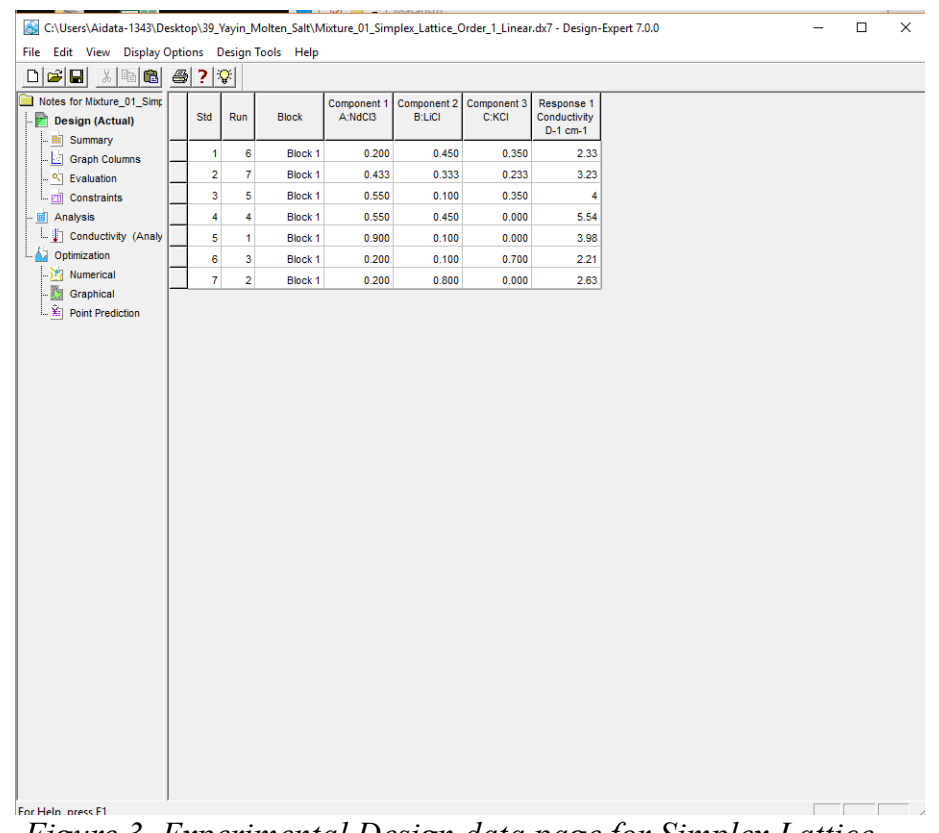

Figure 3. Experimental Design data page for Simplex Lattice

Following model selection by the soft-ware it was introduced the process factor limits and the process factors with responses measured experimentally given in Table 1 and Table 2 to the program for each run, transformed factors with responses by the soft-ware in real and pseudo forms were shown on Table 3 and Table 4. Comparing of the results of Table 1, Table 2, Table 3 and Table 4 it could be understood that all boundaries of mixture compositions and conductivities as response converted to new values in these forms. Examining the results, as the composition of $\mathrm{NdCl} 3$ salt were 0.2 and 0.9 , of $\mathrm{LiCl}$ salt 0.1 and 0.8 , of $\mathrm{KCl}$ salt 0 and 0.7 , and as the conductivities of $\mathrm{NdCl} 3$ salt were 2.21 $\Omega-1 \mathrm{~cm}-1$ and $5.54 \Omega-1 \mathrm{~cm}-1$ experimentally, transformed forms of all these values be rearranged among their upper and lower limits but the boundaries of all factors in pseudo form be rearranged between 0 and 1 .

\section{2. . Statistically Evaluation}

After the model selection, defined the process factor limits, the process factors with responses measured experimentally and transformed all parameters into design form by the soft-ware and then statistically evaluation was carried out. Calculated correlation coefficients of response surface function for with linear, quadratic and cubic terms and its parameters, function constants, one by one for pseudo and actual factors are given in Table 5. Examining the Table 5 it could be understood that as the correlation coefficient would be 0.55 for used linear terms only, adding quadratic terms into the function it increases to 0.92 drastically, but because of the over specified the function parameters for adding cubic terms be invalid. Simulation of response surface function with linear and quadratic terms for optimization was given on Figure 4 and Figure 5, respectively. Comparing Figure 4 and Figure 5 the correlation between the response surface function and the factors using the function with quadratic terms for optimization is more dependable according to that of the function with linear terms only. 


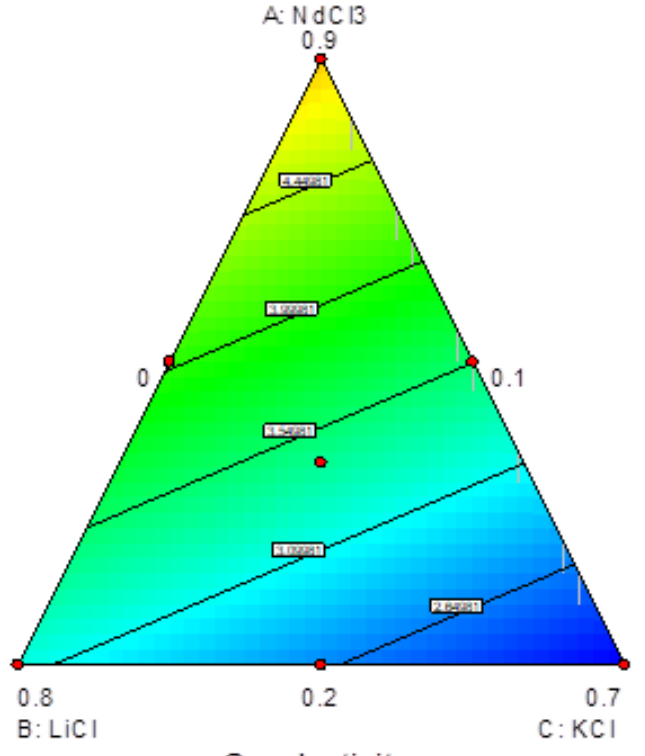

Conductivity

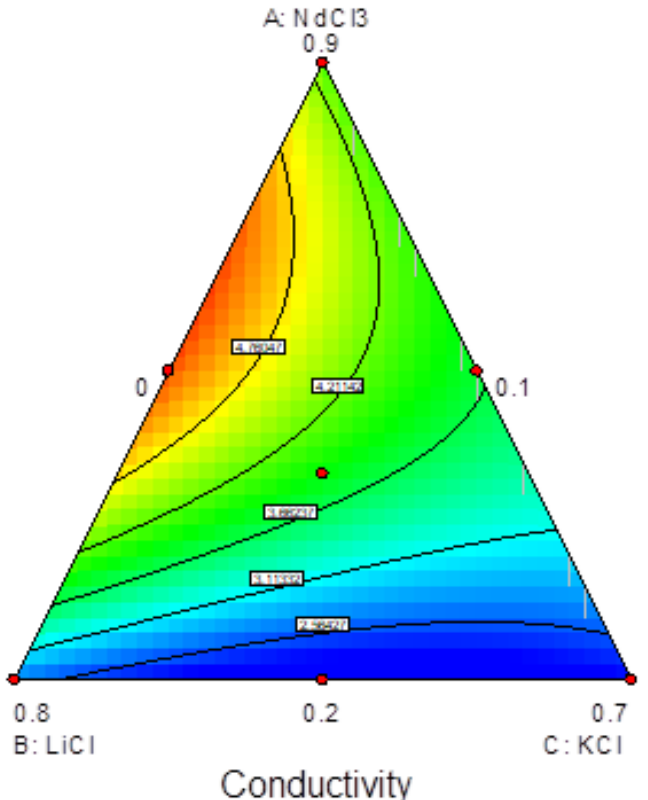

Conductivity
Figure 4. Simulation of response surface function with linear terms
Figure 5. Simulation of response surface function with quadratic terms

Table 3. Transformed factors with responses in real form

\begin{tabular}{|l|l|l|l|l|l|l|}
\hline & & & Com 1 & Com 2 & Com 3 & Res 1 \\
\hline Std & Run & Blo & $\mathbf{A : N d C l} \mathbf{3}$ & $\mathbf{B : L i C l}$ & $\mathbf{C : K C l}$ & Conduc \\
\hline & & & $\%$ & \% & \% & D-1 cm-1 \\
\hline 1 & 6 & 1 & 0.2 & 0.45 & 0.35 & 2.33 \\
\hline 2 & 7 & 1 & 0.43 & 0.33 & 0.23 & 3.23 \\
\hline 3 & 5 & 1 & 0.55 & 0.1 & 0.35 & 4 \\
\hline 4 & 4 & 1 & 0.55 & 0.45 & 0 & 5.54 \\
\hline 5 & 1 & 1 & 0.9 & 0.1 & 0 & 3.98 \\
\hline 6 & 3 & 1 & 0.2 & 0.1 & 0.7 & 2.21 \\
\hline 7 & 2 & 1 & 0.2 & 0.8 & 0 & 2.63 \\
\hline
\end{tabular}

Table 4. Transformed factors with responses in pseudo form

\begin{tabular}{|l|l|l|l|l|l|l|}
\hline & & & Com 1 & Com 2 & Com 3 & Res 1 \\
\hline Std & Run & Blo & $\mathbf{A : N d C l} \mathbf{3}$ & B:LiCl & C:KCl & Conduc \\
\hline & & & $\%$ & $\%$ & $\%$ & D-1 cm-1 \\
\hline 1 & 6 & 1 & 0 & 0.5 & 0.5 & 2.33 \\
\hline 2 & 7 & 1 & 0.33 & 0.33 & 0.33 & 3.23 \\
\hline 3 & 5 & 1 & 0.5 & 0 & 0.5 & 4 \\
\hline 4 & 4 & 1 & 0.5 & 0.5 & 0 & 5.54 \\
\hline 5 & 1 & 1 & 1 & 0 & 0 & 3.98 \\
\hline 6 & 3 & 1 & 0 & 0 & 1 & 2.21 \\
\hline 7 & 2 & 1 & 0 & 1 & 0 & 2.63 \\
\hline
\end{tabular}


Table 5. . Calculated correlation coefficients and its parameters of response surface function for pseudo factors

\begin{tabular}{|c|c|c|c|c|}
\hline Conduc. & Pseudo & Actual & Factors & $\mathbf{R}$ \\
\hline \multirow[t]{4}{*}{ Linear Terms } & $=$ & $=$ & & \\
\hline & 4.89981 & 5.149524 & $* \mathrm{~A}$ & 0.55 \\
\hline & 3.15181 & 2.652381 & $* \mathrm{~B}$ & \\
\hline & 2.19981 & 1.292381 & $* \mathrm{C}$ & \\
\hline \multicolumn{5}{|l|}{ Quadr } \\
\hline \multirow[t]{6}{*}{ Terms } & 4.052652 & 3.023146 & $* \mathrm{~A}$ & 0.91 \\
\hline & 2.702652 & -0.43338 & $* \mathrm{~B}$ & \\
\hline & 2.282652 & 1.508057 & $* \mathrm{C}$ & \\
\hline & 7.48697 & 15.27953 & $* \mathrm{~A} * \mathrm{~B}$ & \\
\hline & 2.16697 & 4.422387 & $* \mathrm{~A} * \mathrm{C}$ & \\
\hline & -1.81303 & -3.70006 & $* \mathrm{~B} * \mathrm{C}$ & \\
\hline Cubic & Over & Over & & \\
\hline Terms & satisfied & satisfied & - & - \\
\hline \multicolumn{5}{|c|}{$y=b 0+b_{1} x_{1}+b_{2} x_{2}+b_{3} x_{3}+b_{12} x_{1} x_{2}+b_{13} x_{13}+b_{23} x_{2} x_{3}+b_{123} x_{1} x_{2} x_{3}$} \\
\hline \multicolumn{5}{|c|}{$\boldsymbol{A}=\boldsymbol{N d C l} \boldsymbol{l}_{3}=x 1, \boldsymbol{B}=\boldsymbol{L i C l}=x_{2}$ and $\left.\boldsymbol{C}=\boldsymbol{K C l}=x_{3}\right)$} \\
\hline
\end{tabular}

\section{Conclucion}

Mixer design is a special type of response surface model and a very effective method of determining the proportions of variables or components in a mixture. As to salt mixtures, molten salts are used as high temperature heat transfer media in many industries. In this context, this study focuses on mixture design and statistically evaluation of its results as an example of experimental design applications. For this purpose, it was selected a molten salt system consisting of three components with conductivities experimentally to investigate the conductivity according to the relative proportion of each component. Here selected mixture design model for optimization of process parameters was Simplex Lattice and used software for statistically evaluation was Design Expert 700 program. After model selection and transformation, all factors and responses to the design, correlation coefficients of the response surface function in linear, quadratic and cubic terms, and pseudo and real factors were calculated. Comparing the correlation coefficients of the response surface functions having with different terms it is understood that the correlation coefficient

\section{References}

Akpolat, O., (2016), "Experimental Design Methods with Practical Applications", Journal of ongoing Chemical Research Vol:2, Iss:2, 64-80.
Brereton, R. G, (2003), Chemometrics: Data Analysis for thje Laboratory and Chemical Plant, John Wiley \& Sons Ltd., UK.

Buruk Sahin, Y., Aktar Demirtaş, E., and Burnak, N., (2016), "Mixture design: A review of recent applications in the food industry”, Pamukkale Univ. Muh. Bilim. Derg., 22(4), 297 304.

Coskun, B., Akpolat, O. (Advisor-Supervisor), (2012), Experimental design and optimization of enzymatic removal for waste water textile color, MSc thesis, BAP201250, Funded by Muğla Sitkı Koçman Uni. Sci. Res. Prj. Offic..

DesignExpert v.7., (2005), Welcome to Help, Content, Stat-Ease, Inc., Copyright $\odot 2005$.

http://moltensalt.org/whatIsMoltenSalt.html, (2019), “What are Molten Salts?", 26.08.2019.

Li, X., Wua, S., Wanga, Y., and Xiea, L., (2018), "Experimental investigation and thermodynamic modeling of an innovative molten salt for thermal energy storage (TES)", Applied Energy, 212, 516-526.

Nunes, V.M.B., Queirós, C.S., Lourenço, M.J.V., Santos, F.J.V., and Nieto de Castro, C.A., (2016), "Molten salts as engineering fluids - A review Part I. Molten alkali nitrates", Applied Energy, 183, 603-611.

Özdemir, D., (2012), Kemometri Temel Eğitimi, Ders Notları, Kimya Akademisi, Antalya. 